\title{
Ascertaining Organizational Commitment Via Workplace Spirituality among Employees of a Malaysian Development Bank
}

Muhamad Khalil Omar, Mohamad Fahimi Ahmad, Rusalbiah Che Mamat, Faizatul Akmam Amirrudin, Nurul Asyiqin Nordi

To Link this Article: http://dx.doi.org/10.6007/IJARAFMS/v12-i1/11992 DOI:10.6007/IJARAFMS /v12-i1/11992

Received: 13 November 2021, Revised: 18 December 2021, Accepted: 30 December 2021

Published Online: 20 January 2022

In-Text Citation: (Omar et al., 2022)

To Cite this Article: Omar, M. K., Ahmad, M. F., Mamat, R. C., Amirrudin, F. A., \& Nordi, N. A. (2022).

Ascertaining Organizational Commitment Via Workplace Spirituality among Employees of a Malaysian Development Bank. International Journal of Academic Research in Accounting Finance and Management Sciences, 12(1), 155-165.

Copyright: @ 2022 The Author(s)

Published by Human Resource Management Academic Research Society (www.hrmars.com) This article is published under the Creative Commons Attribution (CC BY 4.0) license. Anyone may reproduce, distribute, translate and create derivative works of this article (for both commercial and non-commercial purposes), subject to full attribution to the original publication and authors. The full terms of this license may be seen at: http://creativecommons.org/licences/by/4.0/legalcode

Vol. 12, No. 1, 2022, Pg. 155 - 165

Full Terms \& Conditions of access and use can be found at http://hrmars.com/index.php/pages/detail/publication-ethics 


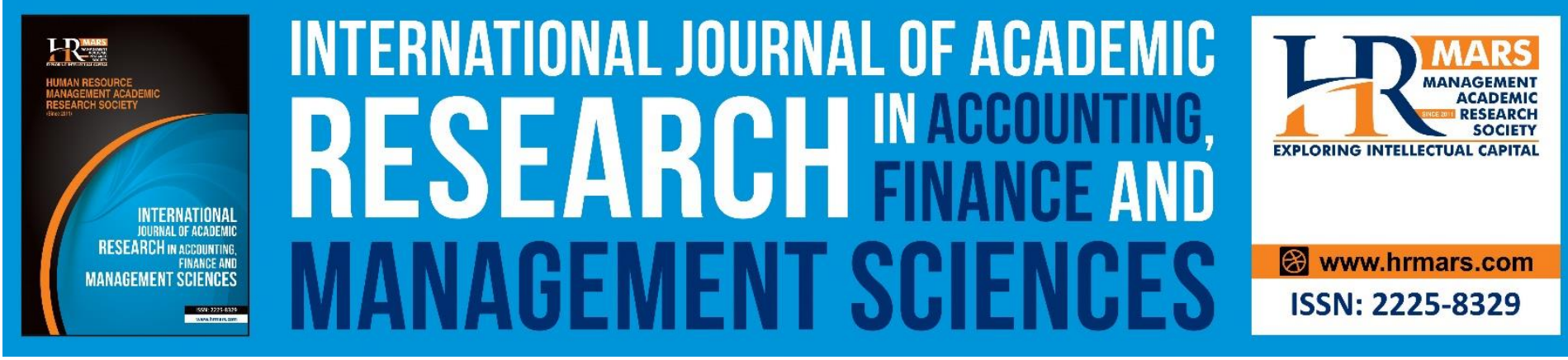

\title{
Ascertaining Organizational Commitment Via Workplace Spirituality among Employees of a Malaysian Development Bank
}

\author{
Muhamad Khalil Omar, Mohamad Fahimi Ahmad, Rusalbiah \\ Che Mamat, Faizatul Akmam Amirrudin, Nurul Asyiqin Nordi \\ Faculty of Business and Management, Universiti Teknologi MARA, Cawangan Selangor, \\ Kampus Puncak Alam, 42300, Bandar Puncak Alam, Selangor, Malaysia \\ Corresponding Author Email: fahimi6301@uitm.edu.my
}

\begin{abstract}
Workplace spirituality is an organisational value that evidenced in the culture to promote employees' experience of transcendence through the work process, facilitating their sense of being connected to others in a way that provides feelings of completeness and joy. Hence, the study of the effects of this value is very much important especially towards the organizational commitment among employees. Therefore, main objective of this research is to determine the effects of workplace spirituality on organizational commitment among employees in one of the development bank in Malaysia. In this study, the dimensions of workplace spirituality included are the sense of community, meaningful work, and work experience.. The methodology of this research is a quantitative survey that was conducted among 173 employees in the studied development bank headquarter in Kuala Lumpur, Malaysia. A standardized questionnaire is used in collecting data and all measurement items in the questionnaire had been adapted from the previous study. Proportionate stratified random sampling was the sampling method of this study. SPSS version 25.0 software is used by the researcher to analyse the primary data and test the hypotheses. A regression test had been used in this research to test the relationship between variables. The findings indicated that sense of community and meaningful work were significantly affecting organizational commitment whilst the work experience was not. This study also includes a discussion of the research objectives and recommendations for the organization. It is suggested that future research should extend this study among employees of other type of banks such as commercial and investment as well as other industries so that a coherent understanding could be established
\end{abstract}

\section{Introduction}

The importance and role of workplace spirituality and organizational commitment have been studied by various researchers from time to time. The study was to examine whether workplace spirituality can affect organizational commitment positively or negatively. It is very important for the organizations to have a good commitment in order to move fast, efficient and precise. Thus, by looking at the spirituality at the workplace, it can show the 
MANAGEMENT SCIENCES

Vol. 12, No. 1, 2022, E-ISSN: 2225-8329 @ 2022 HRMARS

commitment in the organization. Spirituality at work is not just about religion or the transformation of people into a particular belief system (Campbell \& Hwa, 2014). Many researchers organized that employees' values are important aspect in improving organizational commitment.

According to Lloyd (1990), organizations with a less sense of workplace spirituality will leave behind those with greater spirituality. This also can show that greater sense of workplace spirituality can increase commitment in the organization which they have a positive value on each individual. Spirituality in itself is most likely critical and not merely a supporting component of organizational profitability. Malik et al (2011) recommends that in the organizational and management development circles, spirituality has gained a better purpose. Based on previous studies, spirituality at work always has a positive impact which have been studied by previous researcher about employees' attitude (Gibbons, 2000).

Lack of organizational commitment may increase turnover rate in some companies as well as can increase turnover rate in Malaysia when there are too many employees leave their company for some reason. Based on Towers Watson (2013), annual the turnover rate of employees increased from 12.3 percent in 2012 to 13.2 percent in 2013 for the Malaysia's general industry. In Malaysia, according to Choo, Desa and Assari, (2016); Lo and Min (2009), it is a common thing occurrence when employees, younger generations, who have grown up in a highly industrialized economy and have many choices to work for, complain and are no longer loyal as in the past and tend to leave their companies because of low commitment in the organization in particular. It is therefore very important that organizations pay more attention to the question of organizational commitment.

According to many researchers, workplace spirituality influenced by meaningful work, sense of community and alignment with organizational values, but this research, workplace spirituality emphasizes sense of community, meaningful work and work experience. Work experience (Pathak, Saxena, \& Jaiswal, 2017) is added to make a new result whether it can affect organizational commitment or not. Therefore, the objective of this study was to identify the effects of workplace spirituality through all of its dimension as per following subobjectives:

1. To examine whether there is an effect of sense of community towards organizational commitment.

2. To ascertain whether there is an effect of meaningful work towards organizational commitment.

3. To appraise whether there is an effect of work experience towards organizational commitment.

\section{Workplace Spirituality}

According to Giacalone and Jurkiewicz (2003) define workplace spirituality as a framework of organizational values that promote the transcendence experience of employees through the process of work, allowing them to relate to others in a way that gives them completeness feelings and happiness. Moreover, Marschke (2007) suggested that spirituality in the workplace is a domain which not directly to God, but to morality and ethics, meaningful work and business ethics. Many researchers applied and defined spirituality at work in terms of the definition of spirituality. Spirituality in the workplace is important at the individual and organizational level of analysis (Kolodinsky et al., 2008; Pawar, 2008). Individual spirituality is a cognitive and affective experience which the employee feels a spiritual relationship and believes with work. Spirituality can be seen at the organizational level as a 
MANAGEMENT SCIENCES

Vol. 12 , No. 1, 2022, E-ISSN: 2225-8329 @ 2022 HRMARS

value reflection that are part of the culture of the organization and are used to inform behaviour, decision- making, and allocation of resources (Kolodinsky et al., 2008). In this study the dimensions of spirituality in the workplace are sense of community, meaningful work, and work experience.

Firstly, the sense of community in spirituality in the workplace means that people see themselves as interconnected and that there is some kind of relationship exists between the inner self and the inner self of other (Rego \& Cunha, 2008). At group level, a significant dimension of spirituality in the workplace is a sense of community in which the spiritual worker has a strong relationship with colleagues (Ashmos \& Duchon, 2000). It involves a sense of being an integral part of the workplace and yet a relationship of interdependence with fellow members (Mitroff \& Denton, 1999). The sense of community enables employees to benefit from loving support, empowerment and colleagues' sincerity (Munda, 2015). Results from Prakoso, Susilo, and Aini (2018) stated that sense of community variable has a significant influence on the organizational commitment variable. Furthermore, referring to Prakoso, Susilo, and Aini (2018), they specified that most respondents' answers lead to increasing organizational commitment. This can be interpreted those employees who believe that coworkers support each other and employees who feel free in expressing their opinions are a form of sense of community which can affect the organizational commitment. Thus, employees will feel unsure about being accepted by another company and employees feel they have a responsibility to keep working.

Next, meaningful work was described as individual experience about his/her work as an important part of life (Duchon \& Plowman, 2005). Essentially, when a spiritual employee considers quality work as an inner expression that is part of the broad goals of life, there is the motivation in his chosen work to seek a deeper meaning and purpose to make a difference in the lives of others (Ashmos \& Duchon, 2000). Meaningful work also can be seen as most important in broad life objectives (Mitroff, 2003). Work is therefore not only seen as forms of stimulating substance and challenges to build character, but also as a platform through which an individual achieves meaning and builds identity at work (Duchon \& Ashmos, 2005). In their study, Rego and Cunha (2008) found that when people experience spirituality in the workplace, they feel more affectionately attached to their organization and feel a sense of commitment and loyalty to their organization. They also suggest that managers can promote organizational commitment by improving the spiritual environment in the organization. Spirituality has important effects on commitment from previous studies, which affects trust and the culture of cooperation within an organization.

Lastly, work experience will be defined as length of experience in each occupation (McDaniel, Schmid, \& Hunter, 1988). There were not many previous researchers studied work experience as one of the dimensions in workplace spirituality. In this study, therefore, the researcher wants to demonstrate that there is a positive relationship between work experience and organization. According to Delaney (2005), work experience identified most significant dimension of workplace spirituality. Based on the study by Pathak, Saxena, and Jaiswal (2017), it shows that work experience and organizational commitment have a positive impact on their study's regression analysis. The results of this study show that workplace spirituality has a positive and significant impact on organizational commitment, for example, the more employees have workplace spirituality, the more committed they are to their organization (Pathak, Saxena, \& Jaiswal, 2017). The theoretical framework is derived from the literature review. 
MANAGEMENT SCIENCES

Vol. 12 , No. 1, 2022, E-ISSN: 2225-8329 @ 2022 HRMARS

Workplace Spirituality

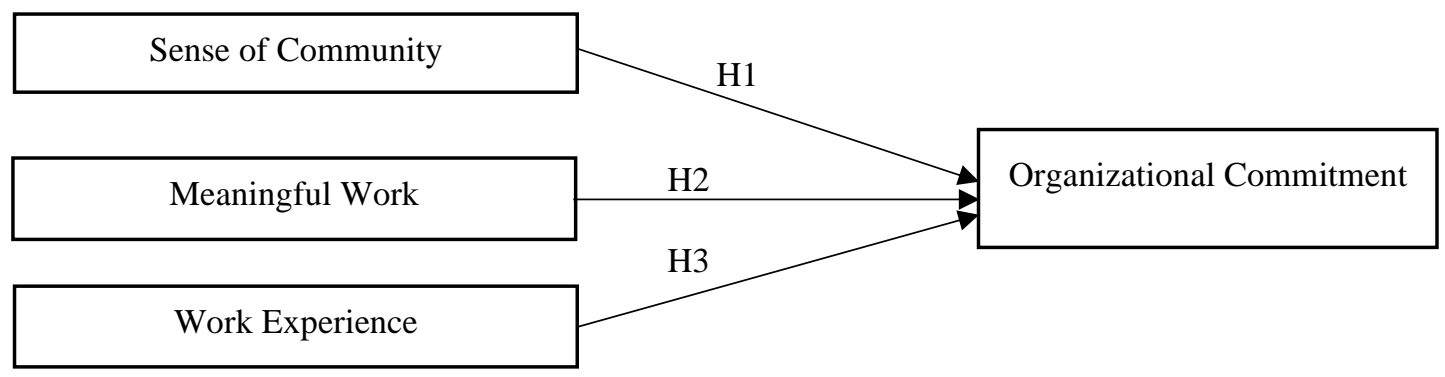

Figure 1. The relationship between Workplace Spirituality on Organizational Commitment

\section{Organizational Commitment}

On the previous years, a lot of research has been done upon the topic of organizational commitment. Apart from that, we have found many definitions from the previous researchers. According to Meyer and Herscovitch's (2001), commitment refers to a psychological force that moves people into ways of acting relevant to a variety of objectives. Organizational commitment is employees' commitment to facilitate the achievement of the organization's objectives and involves the level of employee involvement, identification and loyalty (Caught \& Shadur, 2000). Organizational commitment is the dependent variable in this study. According to Robbins and Judge (2015), organizational commitment is defined as the level, objectives, and expectations of an organization for membership are identified by the worker. Thus, according to previous studies, the spirituality of the workplace has important effects on the commitment that affects trust and the culture of cooperation within an organization. Employees as well as workplace need to have a good spirituality or values to increase their commitment in organization. Based on previous studies on the effect of workplace spirituality (sense of community, meaningful work, and work experience) on organizational commitment, many previous researchers stated that there is positive relationship between workplace spirituality and organizational commitment. Therefore, the hypothesis that can be obtained in this study:

$\mathrm{H} 1$ : $\quad$ There is positive effect on sense of community towards organizational commitment.

$\mathrm{H} 2$ : There is positive effect on meaningful work towards organizational commitment.

H3: There is positive effect on work experience towards organizational commitment.

\section{Methodology}

In this study, quantitative methods of data collection and analysis were used rather than qualitative methods. The type of investigation is correlational. Other than that, time horizon for this research design will be cross sectional. The unit of analysis for this research was therefore individual, which employees were randomly selected from five departments in the surveyed bank. In this research, only five department has been selected to make survey which are Human Resource Management Department, Finance Department, Communication Strategic Department, Retail Banking Department and Digital Banking Department and proportionate stratified random sampling is used which fall under the category of probability. The best-known of the research instruments used for gathering information from people is questionnaire. The questionnaire consists of two parts. The first part is the demographic 
MANAGEMENT SCIENCES

Vol. 12, No. 1, 2022, E-ISSN: 2225-8329 @ 2022 HRMARS

profile of the respondents, while the second part is composed of several sections concerning independent variables (sense of community, meaningful work and work experience) and dependent variable (organizational commitment). For each variable consist of 4 to 7 questions. This questionnaire used the first part of the nominal scale and the second part of the questionnaire used Likert seven points from $1=$ strongly disagreed to $7=$ strongly agreed.

\section{Results \& Discussions}

The researcher has distributed 173 questionnaires to the respondents of the bank's employees. From the distribution of questionnaires, all the questionnaires were returned and usable for analysis. The overall rate of this research was $100 \%$. From the questionnaire distributed, 62.4 percent with 108 respondents are female. Malay respondents are the highest respondents participate in this survey which is $170(37.6 \%)$ respondents. Next, most of respondents aged 41 to 50 years old with 69 (39.9\%) out of 173 respondents. 134 (77.5\%) respondents out of 173 respondents were married people. Then, that most of the respondents' educational level were bachelor's degree which is $64(37.0 \%)$ respondents. Based on the respondents' years of work experience in the company that contribute in this survey that has the highest percentage was respondents that has 4 to 6 years of experience which is $48(27.7 \%)$ respondents. Based on the respondents' years of work experience in this position (including other organization) that contribute in this survey that has the highest percentage was respondents that has 4 to 6 years of experience which is $41(23.7 \%)$ respondents. Other than that, most of the respondents were Clerk/Senior Clerk with 60 (34.7\%) respondents and most of the respondents were from Strategic Communication Department which is 46 (26.6\%) respondents. Lastly, 85 (49.1\%) respondents has income of $\mathrm{RM} 3,000.00$ to $\mathrm{RM} 4,000.00$.

Table 1

Descriptive Statistics

\begin{tabular}{lcccc}
\hline \multicolumn{1}{c}{ Variables } & Mean & $\begin{array}{c}\text { Std. } \\
\text { Deviation }\end{array}$ & Min. & Max. \\
\hline Organizational Commitment & 5.50 & 0.69 & 3.67 & 7.00 \\
Workplace Spirituality: & & & & \\
Sense of Community & 5.54 & 0.66 & 3.00 & 7.00 \\
Meaningful Work & 5.41 & 0.78 & 2.25 & 7.00 \\
Work Experience & 5.39 & 0.80 & 2.25 & 7.00 \\
\hline
\end{tabular}

Based on Table 1, the maximum value for organizational commitment is 7.00 and a minimum value of 3.67. Also, it has a mean of 5.50 which indicate high scores referring to Thaoprom (2004) best principles. The sense of community has the maximum value of 7.00 and minimum value of 3.00 . The mean value for sense of community is 5.54 which also indicate as high scores. Next, the score for meaningful work is within the range 2.25 to 7.00 and the mean is at 5.41 which indicate high scores according to Thaoprom (2004). Lastly, work experience has minimum value of 2.25 and maximum value of 7.00 . While the mean is 5.39 which also indicate as a high score. Overall, sense of community has a highest value of mean and the lowest mean value is work experience. 
MANAGEMENT SCIENCES

Vol. 12, No. 1, 2022, E-ISSN: 2225-8329 @ 2022 HRMARS

As shown in Table 2, result for the reliability statistics in this study shows variable that has the highest Cronbach's Alpha is organizational commitment which is 0.896 (Good) while the second highest Cronbach's Alpha is sense of community which is 0.891 (Good) followed by meaningful work and work experience which are 0.884 (Good) and 0.825 (Good). As a result, all the variables in this research paper are reliable.

Table 2

Reliability Statistics

\begin{tabular}{lccc}
\hline \multicolumn{1}{c}{ Variable } & No of Item & $\begin{array}{c}\text { Cronbach's } \\
\text { Alpha }\end{array}$ & $\begin{array}{c}\text { Strength of } \\
\text { Association }\end{array}$ \\
\hline $\begin{array}{l}\text { Organizational Commitment } \\
\text { Workplace Spirituality: }\end{array}$ & 6 & 0.896 & Good \\
Sense Of Community & 7 & & \\
Meaningful Work & 4 & 0.891 & Good \\
Work Experience & 4 & 0.884 & Good \\
\hline
\end{tabular}

Based on Table 3, it shows the correlation between the dependent variable and independent variables. It shows that the relationship between sense of community, meaningful work and work experience and organizational commitment has positive relationship. The Pearson's Correlation Coefficient between organizational commitment and all independent variables which are sense of community $\left(0.694^{* *}\right)$, meaningful work $\left(0.675^{* *}\right)$ and work experience $(0.429 * *)$ are significant at the 0.01 level according to Table 3. Based on the Guilford's Law, since the P-value is within the range 0.40 to 0.70 , the correlation between organizational commitment and workplace spirituality is moderate correlation. Thus, a substantial relationship is created and significant at the 0.01 level.

Table 3

Data on Pearson's Correlation Analysis

\begin{tabular}{llllll}
\hline \multicolumn{1}{c}{ Variable } & $\begin{array}{c}\text { Organizational } \\
\text { Commitment }\end{array}$ & $\begin{array}{c}\text { Sense Of } \\
\text { Community }\end{array}$ & $\begin{array}{c}\text { Meaningful } \\
\text { Work }\end{array}$ & $\begin{array}{c}\text { Work } \\
\text { Experience }\end{array}$ \\
\hline $\begin{array}{l}\text { Organizational Commitment } \\
\text { Workplace Spirituality: }\end{array}$ & & & & & \\
Sense Of Community & $0.694^{* *}$ & 1 & & & \\
Meaningful Work & $0.675^{* *}$ & $0.656^{* *}$ & 1 & \\
Work Experience & $0.429^{* *}$ & $0.544^{* *}$ & $0.542^{* *}$ & 1 & \\
\hline
\end{tabular}

**. Correlation is significant at the 0.01 level (2-tailed).

Based on Table 4, this study intent to examine the significant effect and the relationship between four variables, namely organizational commitment as the dependent variable and independent variables are sense of community, meaningful work and work experience. The R Square of 0.567 implies that all the independent variables explain 56.7 percent of the variance in dependent variable. Another 43.3 percent of the variance in the dependent variable is not explained by the independent variable in this research. This indicates, there are other independent variables which are not included in this study and could further strengthen the regression equation. 
MANAGEMENT SCIENCES

Vol. 12, No. 1, 2022, E-ISSN: 2225-8329 @ 2022 HRMARS

Next, F-test is significant base on the value of 0.000 . Therefore, all independent variables significantly explained dependent variable. The result for sense of community variable and meaningful work are $0.000(0 \%)$, which is below the $5 \%$ significant level. Therefore, sense of community and meaningful work variables are significant. Thus, it explains that sense of community and meaningful work are positively related with dependent variable. Meanwhile, work experience is not significant because the $p$-value for work experience variable is 0.631 (63.1\%), which is above the $5 \%$ significant level. Hence, this explain that work experience is not related with dependent variable.

Then, for unstandardized beta coefficients are the value of regression equation function for predicting the dependent variable from the independent variable. The column in Table 4 of estimates provides the value for $\beta_{0}, \beta_{1}, \beta_{2}$ for this equation.

Organizational Commitment $=1.106+0.474$ Sense of Community +0.352 Meaningful Work -0.026 Work Experience

For each one-unit increase in sense of community and meaningful work, organizational commitment will increase by 0.474 units and 0.352 units with holding other independent variable constant. In other hand, for each one-unit increase in work experience, organizational commitment will decrease by 0.026 units with holding other independent variable constant. In addition, based on standardized beta coefficients in Table 4 , the beta uses a standard unit that is the same for all variables in the equation. It tells the same as unstandardized beta value but is expressed as standard deviation. As sense of community and meaningful work increase by one standard deviation, organizational commitment increases by 0.450 and 0.396 of a standard deviation. Next, as work experience increase by one standard deviation, organizational commitment decreases by 0.030 of a standard deviation. As a result, the strongest would be sense of community with a beta weight of 0.450 . The weakest would be meaningful work with a beta weight of 0.396 . While work experience variable does not explain the variance in organizational commitment significantly.

Table 4

Regression Analysis Results

\begin{tabular}{|c|c|c|c|c|c|}
\hline \multirow[t]{2}{*}{ Model } & \multicolumn{2}{|c|}{$\begin{array}{l}\text { Unstandardized } \\
\text { Coefficients }\end{array}$} & \multirow{2}{*}{$\begin{array}{c}\text { Standardized } \\
\text { Coefficients } \\
\text { Beta } \\
\end{array}$} & \multirow[t]{2}{*}{$\mathrm{t}$} & \multirow[t]{2}{*}{ Sig. } \\
\hline & $B$ & Std. Error & & & \\
\hline (Constant) & 1.106 & .314 & & 3.524 & .001 \\
\hline Sense Of Community & .474 & .074 & .450 & 6.410 & .000 \\
\hline Meaningful Work & .352 & .062 & .396 & 5.645 & .000 \\
\hline Work Experience & -.026 & .055 & -.030 & -.481 & .631 \\
\hline F Value & & & 73.645 & & \\
\hline Sig. & & & .000 & & \\
\hline Adjusted R Square & & & 0.559 & & \\
\hline R Square & & & 0.567 & & \\
\hline
\end{tabular}


MANAGEMENT SCIENCES

Vol. 12 , No. 1, 2022, E-ISSN: 2225-8329 @ 2022 HRMARS

\section{Conclusion}

The main objective of this research is to determine the effects of workplace spirituality towards organizational commitment in the studied development bank. First hypothesis $(\mathrm{H} 1)$ and second hypothesis $(\mathrm{H} 2)$ of this study are accepted where sense of community and meaningful work has significant positive relationship on organizational commitment. Meanwhile, the third hypothesis $(\mathrm{H} 3)$ of this study are not accepted where work experience is not significant relationship on organizational commitment. Thus, from the regression analysis, it was found that sense of community has the most significant effect on organizational commitment in the bank based on the regression analysis and as a recommendation that can be recommended to the bank to increase more in sense of community in the organization by creating a support systems or programmes. Creating support systems or programmes are to encourage employees to socialize with people around them so that they can feel confident and have a high self-esteem. Other than that, organizations also can implement award system which celebrate a job well done by employee and increase their performance. These can make employees feel part of the community and team.

For meaningful work, in order to have a high organizational commitment, organizations need to give their employees a work that have meaning to their inner motivations which employees can feel motivate to come to the workplace, employees feel energized to do their work and looking forward to come to the workplace. Employees also need to have their own goal to be part of the organizations by doing their work that can share their values and be success in future. Employees need to find something that align with their vision and organizations also need to need to pay attention when hiring employees. Organizations need to hire employees that have an experience which suitable with the job, so that employees will have motivations to do the job that they like. Therefore, future researcher may need to conduct this study with different independent variables which different variable with this study that can give effect to organizational commitment. As the trend in organization is changing from time to time, the management system may be improved. Thus, future researcher can conduct the study to find out is there any improvement regarding organizational commitment.

\section{Acknowledgement}

This research was funded by Universiti Teknologi MARA, file no 600-TNCPI 5/3/DDF (FPP) (002/2020).

\section{References}

Rego, A., \& Cunha, M. P. (2008). Workplace Spirituality and Organizational Commitment: An Empirical Study. Journal of Organizational Change Management.

Ashmos, D. P., \& Duchon, D. (2000). Spirituality at Work: A Conceptualization and Measure. Journal of Management Inquiry.

Beheshtifar, M., \& Zare, E. (2013). Effect of Spirituality in workplace on Job Performance:. Interdisciplinary Journal of Contemporary Research Business.

Bishnoi, N. K. (2012). Workplace Spirituality and Indian Ethos. Purushartha.

Breytenbach, C. (2016). The relationship between three constructs of spirituality and the resulting impact on positive work outcomes.

Brown, R. (2003). Organizational spirituality: the sceptic's version. Organization. 
MANAGEMENT SCIENCES

Vol. 12, No. 1, 2022, E-ISSN: 2225-8329 ๔ 2022 HRMARS

Campbell, J. K., \& Hwa, Y. S. (2014). Workplace Spirituality and Organizational Commitment Influence on Job Performance among Academic Staff. Jurnal Pengurusan.

Caught, K., Shadur, M. A., \& Rodwell, J. J. (2000). The measurement artifact in the organizational commitment questionnaire. Psychological Reports.

Choo, J. L., Desa, N. M., \& Asaari, M. H. (2016). Flexible working arrangement toward organizational commitment and work-family conflict. Studies in Asian Social Science .

Claude, J. Z. (2003). Workplace spirituality and organizational performance . Public Administration Review.

Dehler, G. E., \& Welsh, M. A. (2015). The Experience of Work: Spirituality and the New Workplace.

Doane, D., \& Seward, L. E. (2011). Measuring Skewness: A Forgotten Statistic? Journal of Statistics Education.

Duchon, D., \& Plowman, D. A. (2005). Nurturing The Spirit At Work: Impact on Work Unit Performance.

Fanggidae, R. E., Suryna, Y., Efendi, N., \& Hilmiana. (2016). Effect of a Spiritualit Workplace on Organizational Commitment and Job Satisfaction. Social and Behavioral Science.

Giacalone, R. A., \& Jurkiewicz, C. L. (2003). Handbook of workplace spirituality and organizational performance.

Gibbons, P. (2000). Spirituality at work: definitions, measures, assumptions, and validity.

Harrington, W. J., Preziosi, R. C., \& Gooden, D. J. (2001). Perceptions of workplace spirituality among professionals and executives. Employee Responsibilities \& Rights Journal.

Hudson, R. (2014). The question of theoretical foundations for the spirituality at work movement. Journal of Management, Spirituality and Religion.

Kolodinsky, R. W., Giacalone, R. A., \& Jurkiewicz, C. L. (2008). Workplace values and outcomes: Exploring personal organizational, and interactive workplace spirituality. Journal of Business Ethics.

Lo, M.-C., Ramayah, T., \& Min, H. W. (2009). Leadership styles and organizational commitment: A test on Malaysia manufacturing industry. African Journal of Marketing Management.

Malik, M. E., Naeem, B., \& Ali, B. B. (2011). How Do Workplace Spirituality and Organizational Citizenship Behavior influence Sales Performance of FMCG Sales Force. Interdisciplinary Journal of Contemporary Research in Business.

McDaniel, M. A., Schmid, F. L., \& Hunter, J. E. (1988). Job Experience Correlates of Job Performance. Journal of Applied Psychology.

Meyer, J. A. (2001). Commitment in the Workplace: Toward a General Model. HumanResource Management Review.

Milliman, J., Czaplewski, A. J., \& Ferguson, J. (2003). Workplace spirituality and employee work attitudes: An exploratory empirical assessment. Journal of Organizational Change Management.

Mitchell, R. K. (2013). Spiritual identity, stakeholder attributes and family business workplace spirituality stakeholder salience. Journal of Management, Spirituality \& Religion.

Mitroff, I. I. (1999). A study of spirituality in the workplace.

Mitroff, I. I., \& Denton, E. A. (1999). A Spiritual Audit of Corporate America: A Hard Look at Spirituality, Religion, and Values in the Workplace: A Hard Look at Spirituality, Religion, and Values in the Workplace.

Mowday, R. T., \& Steers, R. M. (1979). The Measurement of Organizational Commitment. Journal of Vocational Behavior. 
MANAGEMENT SCIENCES

Vol. 12 , No. 1, 2022, E-ISSN: 2225-8329 @ 2022 HRMARS

Mydin, A. A., Abdullah, A. G., \& Pitchay, A. A. (2018). Workplace Spirituality Enhance Organisational Commitment in the School Management. Asian Journal of Public Administration and Law.

Nur, Y. O. (2006). Selected organizational outcome correlates of spirituality in the workplace. Psychological Reports.

Osman-Gani, A. M., Hashim, J., \& Yusof, I. (2013). Establishing linkages between religiosity and spirituality on employee performance. Employee Relations.

P., R. S. (2006). Organizational Behavior.

Pathak, R., Saxena, S., \& Jaiswal, G. (2017). Impct of Workplace Spirituality on Organizational Commitment. Prestige International Journal of Management \& IT-Sanchayan.

Pawar, B. S. (2008). Two approaches to workplace spirituality facilitation: A comparison and implications. Leadership \& Organization Development Journal.

Piryaei, S. Z. (2013). Workplace spirituality and positive work attitudes: The moderating role of individual spirituality. Indian Journal of Economics and Development.

Prakoso, A. R., Susilo, H., \& Aini, E. K. (2018). Pengaruh Spiritualitas di Tempat Kerja terhadap Komitmen Organisasional. Jurnal Administrasi Bisnis .

Prem, R. O. (2017). Thriving on challenge stressors? Exploring time pressure and learning demands as antecedants of thriving at work. Journal of Organizational Behavior.

Rahimi, A. S. (2011). The relationship between job spirituality and the citizenship behavior among the staff and students of the state university of Tabriz.

Rashid, M. Z., Sambasivan, M., \& Johari, J. (2003). The influence of corporate culture and organisational commitment on performance. Journal of Management Developmen.

Robbins, S. P., \& Judge, T. A. (2015). Perilaku Organisasi (Organisasi Behavior).

Tahere, N., Zahra, G., Fateme, D., \& Asma, Y. (2012). Investigating the Effects of Job Experience, Satisfaction, and Motivation on Organizational Commitment. Research Journal of Recent Sciences.

Van Tonder, C. L. (2009). A Spirited Workplace: Employee Perspectives on the Meaning of Workplace Spirituality. Journal of Human Resource Management.

Vandenberghe, C. (2011). Workplace spirituality and organizational commitment: an integrative model. Journal of Management Spirituality \& Religion. 